WIELKIE TEMATY KULTURY W LITERATURACH SKOWIAŃSKICH

Slavica Wratislaviensia CLXVIII • Wrocław 2019•AUWr No 3875

DOI: 10.19195/0137-1150.168.43

Data przesłania artykułu: 18.09.2017

Data akceptacji artykułu: 4.12.2017

EWA SZPERLIK

Uniwersytet im. Adama Mickiewicza w Poznaniu, Polska

\title{
Zapiski z „Miasta Umarłych”. Obóz koncentracyjny Jasenovac i Stara Gradiška w literackich narracjach tanatologicznych i dyskursie pamięci obszaru postjugosłowiańskiego
}

Po zakończeniu drugiej wojny światowej tematyka ustaszowskich obozów śmierci była dla władz komunistycznej Jugosławii, posługując się terminem Sławomira Buryły — „prawdami niechcianymi”1. W ostatnim ćwierćwieczu w warunkach ukonstytuowania się państw narodowych po rozpadzie Jugosławii pamięć drugiej wojny światowej i podjęte próby rozliczenia stały się nieodłącznym elementem rewizji własnej historii dla niemalże wszystkich republik byłej Jugosławii. Warto przypomnieć, że obóz koncentracyjny Jasenovac, zwany też obozem śmierci - w państwie NDH (Nezavisna Država Hrvatska - NDH, 1941-1945), funkcjonował jako Zapovjedničtvo sabirnih logora Jasenovac ${ }^{2}$, powstał na mocy dyrektywy wydanej przez Eugena Dida Kvaternika w połowie roku 1941. Budowę i prace przy nasypie rzeki Sawy mieli rozpocząć sami więźniowie.

Dužnost izgradnje Jasenovaca imaju logoraši, koji će na taj način ispraviti svoje „zločine” učinjene prema domovini. Jasenovac je ujedno i politička škola, koja iskreno želi da ,političke zatočenike” izliječi od svih otrovnih političkih pogleda i ideologija i da ih vrati

${ }^{1}$ S. Buryła, Prawdy niechciane i potrzeba ich społecznej artykulacji, [w:] Pamięć Shoah. Kulturowe reprezentacje i praktyki upamiętniania, red. A. Ziedler-Modlewska, T. Majewski, Łódź 2011, s. 361-482.

2 N. Mataušić, Jasenovac 1941.-1945. Logor smrti i radni logor, Jasenovac-Zagreb 2003, s. 29. 
u javni život, te ih tako učini korisnim članovima društva i dostojnim sinovima domovine.

Židovi ostaju u logoru do kraja rata ${ }^{3}$.

Obóz Stara Gradiška (Ustaška obrana, Zapovjedničtvo sabirnih logora Stara Gradiška) ${ }^{4}$ różnił się od miejsca, jakim był Jasenovac, tym, że przywożono tam głównie tak zwanych więźniów politycznych, antyfaszystów, komunistów z wszystkich regionów Chorwacji, BiH, kobiety - Chorwatki, Żydówki, Serbki, a od czerwca 1942 roku także dzieci, przede wszystkim narodowości serbskiej. Było to więzienie i areszt usytuowane na lewym brzegu rzeki Sawy, które działało już od 1799 roku, wzniesione jako twierdza przez internowanych więźniów francuskich. Oba obozy oraz ich liczne „filie" propagandą medialną, były obozami pracy i więzieniem dla przeciwników politycznych reżimu Ante Pavelicia ${ }^{6}$. Chociaż oficjalnie nadzór nad obozami sprawowali ustasze, ich funkcjonowanie ściśle było związane z interesami Trzeciej Rze$\mathrm{szy}^{7}$. Masowe likwidacje więźniów wykonywano w pobliskim lesie i w czasie tak zwanych prac na zewnątrz, poza terenem obozu. Jak podaje Radovan Trifunčić, była to „przerażająca negacja cywilizacji”" .

Autorzy wybranych autobiograficznych wspomnień i narracji tanatologicznych, eksponujących doświadczenie śmierci w warunkach obozowych (Jasenovac i Stara Gradiška), podobnie jak dziesiątki tysięcy współwięźniów, zostali zapędzeni do miejsc za drutem kolczastym, a kiedy, zdoławszy przeżyć, je opuścili, spisali swoje wspomnienia. Jednakże świadectwa te poddano ostrej cenzurze i w efekcie zabroniono ich publikacji. Za dobitny przykład zjawiska manipulacji pamięcią o obozach koncentracyjnych na terenie Chorwacji i byłej Jugosławii może posłużyć autobiograficzny zapis Konclogor na Savi (Konzor, Zagreb 1999) Iliji Jakovljevicia (1898-1948), pisarza, publicysty i adwokata, który popełnił samobójstwo w roku 1948. Z powodu odrzucenia propozycji współpracy z reżimem ustaszowskim w 1941 roku trafił on na rok do obozu koncentracyjnego Jasenovac. Książka I. Jakovljevicia Konclogor na Savi ukazała się drukiem dopiero w roku 1999, mimo że rękopis został ukończony już na Wielkanoc 1943 roku. Podobnym przypadkiem jest obozowe świadectwo Milka Riffera (1908-1972) Grad Mrtvih

${ }^{3}$ M. Riffer, Grad Mrtvih Jasenovac 1943, Zagreb 2011, s. 19-20.

${ }^{4}$ N. Mataušić, Jasenovac 1941-1945..., s. 99.

${ }^{5}$ Do miejsc pamięci związanych z działalnością obozów Jasenovac i Stara Gradiška należą Gradina, Bjelavine, Kujovača, w których odkryto i w roku 1964 zbadano masowe groby. Trzy rodzaje grobów: groby, do których przywożono żywych więźniów, i tam zabijano; groby trupów, groby ugotowanych lub nadpalonych kości. W innych jamach znajdywano same czaszki, zgodnie z hipotezą, że pozostałe części ciał ofiar wcześniej się rozpadły albo też były to masowe groby czaszek więźniów, których ciała wrzucano do Sawy; R. Trifunčić, Jasenovac, Daruvar 1974, s. 35, 38.

${ }^{6}$ Ibidem, s. 13.

${ }^{7}$ Za unikanie pracy groziła natychmiastowa śmierć. Więźniowie byli likwidowani najczęściej tępymi narzędziami i nożami, a szczątki ludzkie palono na prowizorycznym urządzeniu nazywanym ,grill”. Popiół i nadpalone części ludzkich ciał odwożono oddzielnie zbudowaną w tym celu kolejką wąskotorową na brzegu Sawy; ibidem, s. 30-32.

8 Ibidem, s. 17, 22, 28. 
Jasenovac 1943 (2011). Osobista optyka M. Riffera na temat obozu koncentracyjnego na Sawie, choć w wymowie bardzo drastyczna, kłóciła się z oficjalnym wizerunkiem Jasenovaca, jaki po wojnie narzucała propaganda komunistycznej Jugosławii. Książka Riffera została wycofana z wystaw sklepowych, a następnie zakazana. Władze komunistycznej Jugosławii niechętnie eksponowały narracje o miejscach takich jak Jasenovac i Stara Gradiška, tłumiono je w miarę możliwości, mając na względzie zachowanie spokoju między republikami. Niewygodna politycznie okazała się także książka Đorđa (Jury) Milišy U mučilištu-paklu Jasenovac (2011), napisana w roku 1945, opublikowana w 1946. Jeszcze w tym samym roku jej dystrybucja została objęta zakazem sądowym, wiele egzemplarzy spalono. Do jej negatywnego przyjęcia przyczyniło się niejasne stanowisko władz jugosłowiańskich w stosunku do obozu w Jasenovacu. Nakładem wydawnictwa Naklada Pavičić w roku 2011 ukazało się też pierwsze wydanie wspomnień Ante Ciligi (Jasenovac: ljudi pred licem smrti), intelektualisty, pochodzącego z Istrii dysydenta i oponenta Tity. We wrześniu 1941 A. Ciliga został aresztowany i umieszczony w Jasenovacu do końca roku $1942^{9}$. W pierwszym, emigracyjnym, wydaniu wspomnień Sam kroz Europu u ratu (1978) Ciliga opisał więzienia ustaszowskie oraz obóz w Jasenovacu, a także nakreślił atmosferę środowisk intelektualnych i dziennikarskich w Zagrzebiu lat 1943-1944. Już w roku 1965 w literaturze omawianego regionu niezwykle odważną wypowiedzią stała się książka Antuna Baraca, wielkiego formatu historyka literatury chorwackiej i jednocześnie byłego więźnia obozów Jasenovac i Stara Gradiška — Bijeg od knjige (1965). Książka powstała w warunkach obozowych, ukończona w roku 1945, wydana pośmiertnie, jednak jej pojawienie się całkowicie przeszło bez echa i była ona w dyskursie publicznym zupełnie przemilczana. „Nije još vrijeme da se objavi. Suviše smo blizu događajima, a knjiga ima lični karakter"10. Barac razem z Milišą trafili do Jasenovaca, a potem Starej Gradiški, 10/11 listopada 1941 roku, jako przeciwnicy polityczni reżimu A. Pavelicia i zwolennicy idei jugoslawizmu.

Przytaczając słowa Hannah Arendt: „Obozy koncentracyjne oraz obozy zagłady reżimów totalitarnych służą jako laboratoria, w których poddaje się sprawdzeniu podstawowe założenia totalitaryzmu, że wszystko jest możliwe"11. Jasenovac i Stara Gradiška — „bałkańskie obozy śmierci i jugosłowiański Oświęcim” (Ciliga), będące „straszliwą negacją cywilizacji”, to jedno z wielu ogniw w przerażającej mozaice obozów koncentracyjnych rozsianych po całej Europie w czasie drugiej wojny światowej, stając się później przedmiotem niezliczonych wielodyscyplinarnych badań i analiz związanych z Zagładą. Owocem refleksji wynikającej z hermeneutyki wybranych narracji tanatologicznych obszaru postjugosło-

${ }^{9}$ Na podstawie listu gończego, wydanego jeszcze przez policję Królestwa Jugosławii, traktującego Ciligę jako niebezpiecznego komunistę. Skazany na trzy lata (co ze względów biologicznych oznaczało w praktyce karę śmierci), został uwolniony po roku, dzięki interwencji prof. A. Seitza.

10 J. Dragičević, Barčev Bijeg od knjige, [w:] Zbornik o Antunu Barcu, red. T. Maštrović, Zagreb 2014, s. 275.

${ }^{11}$ H. Arendt, Korzenie totalitaryzmu, przeł. D. Grinberg, M. Szawiel, Warszawa 2014, s. 511. 
wiańskiego są dwa dominujące aspekty, szczególnie warte uwagi. Po pierwsze: tematyka wszechobecnej śmierci w warunkach obozowych, zagadnienie śmierci masowej, w kontekście badań nad kondycją ludzką w systemie totalitarnym ${ }^{12}$, w dyskursie postholokaustowym (H. Arendt, Giorgio Agamben, Primo Levi, Dominick La Capra i in.). Po drugie: polityka przemilczeń, jaką władze komunistycznej Jugosławii objęły narracje holokaustowe, dotyczące nie tylko zagłady Żydów, Romów, lecz także Serbów oraz tak zwanych przeciwników politycznych, w tym Chorwatów. Oba aspekty sprawiają, że tematyka obozów koncentracyjnych na terenie Jugosławii miała charakter podwójnego tabu. Nie tylko w czasie trwania Jugosławii od roku 1945 do jej krwawego rozpadu w latach 90. XX wieku, lecz także w późniejszych warunkach posttransformacyjnych. Po roku 1995 manipulowanie pamięcią o ofiarach drugiej wojny światowej dokonuje się na linii dwoistego podziału — konkurencyjności między (prochorwacką) pamięcią o Bleiburgu, która eksponuje naród chorwacki jako ofiarę końca drugiej wojny światowej ${ }^{13}$, a (proserbską) pamięcią o obozie w Jasenovacu i Starej Gradišce ${ }^{14}$, jako miejscach i symbolach narodowych martyrologii ${ }^{15}$.

\section{Śmierć wszechobecna - muzułmanie i żywe trupy}

Literaturę autobiograficznego testymonium określił Jaques Derrida mianem autobio-tanatografii, w ślad za nim Aleksandra Ubertowska pojęciem auto(tanato)grafii, oznaczającej: „relację o własnej śmierci, opisanie własnej (potencjalnej) śmierci i ciągłą gotowość na nią ${ }^{16}$. W narracjach tanatologicznych ocalałych świadków śmierć daje się postrzegać w układzie „historii wertykalnej” (Michele Vovelle), w ramach której łączą się śmierć doznawana, śmierć przeżywana i wypowiedź o śmierci ${ }^{17}$. Śmierć w warunkach obozowych jest wielowymiarowa, przybiera różne formy, jest tyleż wyczekiwana ile nieoczekiwana. Oprócz śmierci w wyniku chorób, wycieńczenia organizmu, głodu, zamarznię-

${ }^{12} \mathrm{H}$. Arendt definiuje podstawowe założenia totalitaryzmu: „Zdrowemu rozsądkowi sprzeciwia się nie nihilistyczna zasada, że »wszystko jest dozwolone«, [...]. Zdrowy rozsądek i »normalni ludzie« nie chcą uwierzyć w to, że wszystko jest możliwe”, ibidem, s. 514-515.

${ }^{13}$ Wzięcie krwawego odwetu w tak zwanej masakrze majowej na żołnierzach Niezależnego Państwa Chorwackiego i zwolennikach reżimu Ante Pavelicia, ale także na ludności cywilnej opuszczającej kraj ze strachu przed widmem bolszewizmu.

${ }^{14}$ Za działaniem obozów kryła się ówczesna polityka reżimu A. Pavelicia, mająca na celu między innymi wyniszczenie narodu serbskiego.

${ }^{15}$ Postjugosłowiańskie obszary pamięci o drugiej wojnie światowej uległy polaryzacji: po jednej stronie znajdują się obozy koncentracyjne Jasenovac i Stara Gradiška (ofiary NDH), po drugiej Bleiburg i pamięć o tak zwanej masakrze majowej z 1945 roku (ofiary titoizmu), dowodzą pęknięcia w sposobie zbiorowego pamiętania wydarzeń związanych z drugą wojną światową, ma także miejsce „nacjonalizowanie” ofiar tych tragedii.

16 A. Ubertowska, Holokaust. Auto(tanato)grafie, Warszawa 2014, s. 45.

${ }^{17}$ M. Vovelle, Historia ludzi w zwierciadle śmierci, przeł. M. Ochab, [w:] Wymiary śmierci, red. D. Dmochowska, T. Swoboda, Gdańsk 2010, s. 35. 
cia, zamordowania, spalenia żywcem itp., jednym z jej aspektów stała się śmierć dobrowolna, samobójcza. Samobójstwo w obozie zyskało status rezygnacji z ,życia" lub po prostu wybawienie od cierpienia. Niejednokrotnie miało ono charakter grupowy, decydowały się na nie całe rodziny. U Jakovljevicia pojawia się następujący fragment:,,Mrkonjić me u nekoliko navrata molio da mu pribavim kakvu uzicu, napose nakon toga što bračni par u susjedstvu pokuša samoubojstvo. - Bit će vam za dušu, gospodine. Nama nema spasa! Meni je jedan ustaša rekao da ćemo biti poubijani" ${ }^{\prime 18}$. Jak pisze H. Arendt:

można zniszczyć właśnie psychikę nie niszcząc człowieka fizycznie, [...] efektem końcowym są nieżywi ludzie, a więc ludzie, których nie można już zrozumieć posługując się psychologią, których powrót do ludzkiego świata zrozumiałego psychologicznie przypomina wskrzeszenie Łazarza ${ }^{19}$.

Istotę ludzką, u której pojawia się powolna rezygnacja z obozowego ,życia”, stawanie się istotą wegetującą, żywym trupem, popadającą w stan swoistego znieczulenia, będący następstwem przeżywania sytuacji granicznej, w dyskursie holokaustowym Giorgio Agamben określił mianem mu zułmana, muzułman, der Muselmann ${ }^{20}$.

Muzułman obozowy unieczynniał kolejno

swoje zmysły, wydziedziczał się ze swoich organów kontaktu ze światem zewnętrznym i z sobą samym, aby nic nie widzieć i nic nie słyszeć więcej, niszczył w sobie możliwość doznawania czegokolwiek, aby znaleźć się poza kresem zbrodni, cudzej i rozpaczy, własnej: wytwarzał w sobie pustkowie. Żywe pustkowie. Wytwarzał w sobie to żywe pustkowie — śmierć psychiczną, śmierć osobowości, znieistnienie własnego ,ja” — ku któremu, jak to okazuje Bettelheim w rozważaniach poświęconych niemieckiemu obozowi koncentracyjnemu jako systemowi niszczenia ludzkiej osobowości, obóz miał człowieka doprowadzić zgodnie z pierwotnym celem, zanim zabijał fizycznie ${ }^{21}$.

Pogodzony z nieuniknionym losem obozowy $\mathrm{m}$ u z u $\mathrm{m}$ m a $\mathrm{n}$ pragnie śmierci, aby wyzwolić się od cierpienia:

Prvo, u čovjeku — zatočeniku stalno je tinjao plamičak nade, da su u mogućnosti bijega s radova izvan kruga logora realniji. Drugo, u potpunoj krizi čovjekove ličnosti mnogi su priželjkivali radove gdje je smrt učestala. Mnogi, a posebno zatočenici koji su bili stariji tražili su u smrti spas od mučenja i patnji ${ }^{22}$.

Zawarte w tytule niniejszego tekstu określenie obozu jako „miasta umarłych", albo miasta (żywych) trupów, pochodzi z książki M. Riffera, Grad Mrtvih. Jasenovac 1943. „Obłąkane masowe wytwarzanie trupów jest poprzedzone zrozumiałym z historycznego i politycznego punktu widzenia przygotowaniem

${ }^{18}$ I. Jakovljević, Konclogor na Savi, Zagreb 1999, s. 43.

19 H. Arendt, Korzenie totalitaryzmu..., s. 515.

${ }^{20}$ G. Agamben, Co zostaje z Auschwitz, przeł. S. Królak, Warszawa 2008, s. 41.

${ }^{21}$ D. Danek, Śmierć wewnętrzna. Literatura w świetle doświadczenia psychoanalitycznego, Gdańsk 2012, s. 12.

22 R. Trifunčić, Jasenovac..., s. 23. 
żywych trupów"23. Obóz jako miejsce wszechobecnej śmierci, posługując się nieco ironicznym językiem Riffera - uzasadnia już na samym początku opis jego makabrycznej „scenerii”. Legowiska więźniów w barakach do złudzenia przypominają trumny: „na ležajima u obliku lijesova. [...] ležaji, kakvih nigdje nikada nisam vidio. Made in Jasenovac" 24 . Powołując się na myśl największych przedstawicieli francuskiej szkoły tanatologicznej ${ }^{25}$ mówiących o zasadach estetyki śmierci (M. Guiomar), holokaustowej desakralizacji śmierci; masowej zagładzie, tabu, pornografii śmierci, braku odpowiedniego języka opisu, a także o śmierci jako władzy nad życiem (M. Foucault), dla dyskursu tanatologicznego niezmiernie istotne pozostają też materialne ślady zjawiska śmierci, jakimi są w normalnych warunkach miejsca pamięci o śmierci: cmentarze, mogiły, nagrobki itp. W warunkach obozów koncentracyjnych stałymi elementami krajobrazu stawały się wypełnione trupami jamy, doły, krematoria, co potęgowało wśród więźniów poczucie śmierci, często własnej, nieuchronnej. Został tam zaburzony podział przestrzeni na sacrum (cmentarz, grób) i profanum (przestrzeń dla żyjących). Ciliga pisze: „Zaista u jednom krajnjem uglu vrta, gdje pokopani nisu bili pokriveni dosta debelim slojem zemlje, osjećao se tih vrućih ljetnih dana oštar vonj raspadajućih se trupla, tako da se moralo bježati od tog ugla" ${ }^{26}$. Pozostali więźniowie żyją jak gdyby na cmentarzysku: „Velike, duboke jame s mnoštvom pogubljenih i od raznih bolesti pomrlih, bile su zasute živim vapnom, dobro zatrpane i izravnane. Nikakav znak nije upućivao da u njima leže mrtvaci. No, glavni su grobovi ipak bili vani po selima" 27 . W realiach obozowych przestrzeń za drutem kolczastym pozostaje więc niezdefiniowana, nie wiadomo, która jej część należy do żywych, a która do zmarłych. Profanacja przestrzeni dokonuje się za sprawą zatarcia granicy na przykład między obozowym ogrodem a cmentarzem, w którego obrębie „funkcjonują” w bezpośredniej bliskości (jeszcze) żywi i (już) zmarli.

\section{Codzienność obozowa - inferno i „ludzkie dno”}

A. Ciliga postrzega miejsce, jakim był obóz Jasenovac, jako „maszynę śmierci”, „kulturę zła”, a także „ludzkie dno”, wspominając jednocześnie o relacjach międzyludzkich, jakie wytworzyły się wśród współwięźniów. Ciliga zauważa: „Logor Jasenovac je velika mašina smrti s jedinom svrhom da jedni budu ubijeni odmah, čim uđu - drugi, s vremenom, prema prilikama ako i sami dotle ne umru [...] modus operandi logora je istrebljenje a njihov glavni proizvod masovna

${ }^{23}$ H. Arendt, Korzenie totalitaryzmu..., s. 521.

${ }^{24}$ M. Riffer, Grad Mrtvih..., s. 131.

${ }^{25}$ L. V. Thomas, Tworzenie tanatologii, przeł. M. L. Kalinowski, [w:] Wymiary śmierci..., s. 19.

26 A. Ciliga, Jasenovac: ljudi pred licem smrti, Zagreb 2011, s. 82.

${ }^{27}$ I. Jakovljević, Konclogor..., s. 116-117. 
smrt"28. Zarządzający więzieniem-obozem dokładali wszelkich starań, aby te relacje były jak najgorsze, co nierzadko się udawało. Między więźniami pojawiały się wzruszające przyjaźnie i gotowość na poświęcenie za innego człowieka, szlachetne przykłady ludzkiej solidarności, ale jednocześnie zwierzęca walka o przetrwanie, w której została obnażona absolutna agambenowska conditio inhumana. Według H. Arendt:

Obozy koncentracyjne można trafnie podzielić na trzy typy odpowiadające trzem podstawowym w krajach Zachodu koncepcjom życia po śmierci: Hades, Czyściec, Piekło. [...] Piekło, w najdosłowniejszym znaczeniu, ucieleśniały udoskonalone przez nazistów typy obozów, w których całe życie było dokładnie i systematycznie zorganizowane z myślą o jak najdotkliwszej udręce ${ }^{29}$.

W niemal całej narracji Đ. Milišy opisującej rzeczywistość obozu Jasenovac przeważa określenie tego miejsca mianem piekła (pakao), zarówno w tytule książki $U$ mučilištu-paklu, jak i wielu jej rozdziałach ${ }^{30}$ : „Pakao se nalazio kraj puta Jasenovac-Novska, a željeznički kolosijek stizao je do pred vrata samog pakla"31. Na obozową codzienność składają się dantejskie sceny grupowych śmierci, o charakterze „taśmowym” (spalanie ludzi w piecach, także żywych ${ }^{32}$ ), odbywające się na otwartej przestrzeni obozu, na oczach współwięźniów.

Jest, odvajani su, išli su u prostorije koje su se zvale bolnicom, ali to nije bila nikakva bolnica, nego sabiralište materijala za krematorij. Tako su radili ovdje, a tako su radili i u Jasenovcu. Pale ljude da se riješe lešina, ne mogu tolike pokopati, treba mnogo vremena dok se rastvore, a osim toga to je i jednostavnije. Dotjeraju ljude u ciglanu, svežu im ruke odzada... svaki se mora stepenicama popeti na peć... tamo ga udare maljem po glavi tako da se sruši ravno u usijanu peć. To ima — kažu — i tu prednost što je ovo higijenski, a osim toga sve se zbiva unutar logora, stranci nemaju uvida ${ }^{33}$.

Więzień Ciliga zauważa, że już „po wszystkim”, u niego i innych współwięźniów pojawia się wzmożony, wręcz „zwierzęcy” apetyt: „Što je me posebno začudilo: poslije ove žestoke scene mogao sam večerati, jeo sam dapače s povećanim apetitom. I ja i ostali gutali smo brzo i odlučno hranu, kao životinje..." ${ }^{34}$. Opisywane obozy zostały przedstawione ponadto jako dobrze prosperujące przedsiębiorstwo recyclingu, w którym nic nie może się zmarnować. Szczególnie odzież straconych jest pozyskiwana, czyszczona, dezynfekowana i magazynowana po uprzedniej ewidencji.

28 A. Ciliga, Jasenovac: ljudi..., s. 5.

${ }^{29}$ H. Arendt, Korzenie totalitaryzmu..., s. 519-520.

${ }^{30}$ Pred paklom, Pakao, Hierarhija pakla, Strahote u paklu, Ponor i dubine pakla III c, Uprave u paklu, Rad i radione u paklu, Zatvori u paklu, Krematorij u paklu, Srpska djeca okoline pakla, Pakao Stara Gradiška, Život u zapovjedništvu pakla, Pobuna u paklu, Iza zidina pakla i in.

31 Đ. Miliša, U mučilištu-paklu Jasenovac, Zagreb 2011, s. 59.

32 A. Ciliga, Jasenovac: ljudi..., s. 49.

${ }^{33}$ I. Jakovljević, Konclogor..., s. 78-79.

${ }^{34}$ A. Ciliga, Jasenovac: ljudi..., s. 50. 
Tamo bi ih iznenada udarili maljem po glavi od one crne legije i pobacali ih u jamu što je bila zaklonjena drvećem. [...] — Što ste učinili s odjelom? — Kad je pao mrak, puštena su na splavi niz vodu do logora. Tamo su dezinficirana i stavljena u skladište. [...] - Jedan se „crnac” šalio kao je šteta toliko ljudskog mesa. Ima tu i ,podebelih” svinja, mogao bi se od njih praviti dobar sapun. U Jasenovcu je zbog toga propalo barem stotinu vagona, na kojima su se mogli silni novci zaraditi. - Glupe šale! Jasenovac ima unosniju industriju. Ciglana radi. - Bome radi! Samo u jednom danu spaljeno je dvanaest tisuća cigana. Proljetos su i odavde vodili bolesnike u taj krematorij ${ }^{35}$.

Riffer, ale i pozostali autorzy, opisuje przerażające warunki sanitarne, jakie panowały w obozie. Setki wycieńczonych, niedożywionych więźniów, cierpiących na permanentne problemy gastryczne, toczyły walkę z nieustającą biegunką, musząc korzystać z prymitywnej i prowizorycznej latryny, będącej źródłem samym w sobie dalszych chorób, powikłań i śmierci.

Latrina je bila najživlje posjećeno mjesto u logoru III C. [...] nalazila se iza kuhinje. Bila je veoma primitivna: obična rupa od $4 \mathrm{~m}$ duljine i po $2 \mathrm{~m}$ širine i dubine. Uzduž i poprijeko bile su položene daske, na kojima je po cijeli dan čučalo preko stotinu logoraša mučenih kroničnim proljevom i dizenterijom, druga stotina čekala je strpljivo spuštenih gaća, da se isprazni koje mjesto na dasci. Bilo ih je koji su satima čučali na dasci i nisu se mogli od nje odvojiti, jer je iz njih lijevalo bez prestanka. Kada sam došao u logor, latrina je bila do vrha napunjena crijevnim izmetom, krvlju i urinom, tako da je sredina daske ležala najmanje 20 $\mathrm{cm}$ ispod površine. Rojevi muha poput oblaka lebdjeli su oko jame, kupali se u žitkoj smjesi i napadali usta inertnih posjetilaca ove ustanove, što je oko sebe širila neopisiv smrad ${ }^{36}$.

Niewolnicza praca, brak higieny i dostępu do wartościowej wody pitnej oraz pożywienia wywoływały liczne choroby (również zakaźne), tyfus plamisty, a także masowe zgony wśród dzieci i noworodków.

Dizenterija i druge crijevne i želučane bolesti kosile su nemilosrdno zatočenike. [...] Oboljevalo se i od hrane, graha. Govorilo se da je i tome kriva voda u kojoj se grah, bez ikakvog začina, kuha. Drugi su govorili da se u hranu nešto sipa i da se od toga kvare unutrašnji organi. Prema onomu što sam ja vidio, mogu reći — [...] da je od ove „prirodne” galopirajuće smrti ginulo ne manje ljudi od onih izravnih likvidacija ${ }^{37}$.

Do stałych elementów tragicznej rzeczywistości obozowej, powodowanej głębokim niedożywieniem i głodem skazanych, należało spożywanie niestrawionych cząstek pokarmu z odchodów współwięźniów: „Većina je oslobadjala svoja zdrava ili bolesna crijeva, no neki posebno izgladnjeli vadili su iz jame izmetine, ostatke naše neprobavljene hrane, i jeli..."38. W jeszcze bardziej przejmującym fragmencie wspomina o tym M. Riffer:

No taj smrad nije mogao smetati one najbjednije, koji nisu ni na što drugo mislili, nego kako će utažiti glad, što je orgijala u njihovim praznim crijevima. Ti kosturi, bivši ljudi,

35 I. Jakovljević, Konclogor..., s. 78.

${ }^{36}$ M. Riffer, Grad Mrtvih..., s. 46-47.

37 A. Ciliga, Jasenovac: ljudi..., s. 36-37.

38 Ibidem, s. 66-67. 
sjedili su oko latrine i kašikama lovili nesvarene dijelove hrane: grah, kukuruz. Neki nisu imali ni vremena da operu lovinu, nego su je izravno prinosili ustima ${ }^{39}$.

\section{„Śmierć nieumarła”}

W obozie Jasenovac masowe likwidacje więźniów odbywały się w okresie zimowym, aby zaoszczędzić na wyżywieniu. „Dolazi zima, prestat će svi vanjski radovi, osim u šumi. Nemaju računa da badava »hrane« trutove. Rješenje je na dlanu: potamaniti ih kao štakore" 40 .

Bestialskie mordy dokonywane na więźniach przez dowodzących obozem, śmierć z głodu, wycieńczenia, profanacja ciał, desakralizacja zwłok, brak pogrzebów i żałoby po zmarłych, pozbawiają śmierci w warunkach obozowych jej religijnego, etycznego, a nawet antropologicznego aspektu ${ }^{41}$. Przytaczając myśl G. Agambena:

W Auschwitz nie umierano, w Auschwitz fabrykowano trupy. [...] nie można już mówić w sensie ścisłym o śmierci. [...] zarówno śmierć, jak umieranie, zarówno umieranie jak jego sposoby, zarówno śmierć jak fabrykowanie trupów stają się od siebie nieodróżnialne ${ }^{42}$.

Według Sonii Ruszkowskiej zgodnie z koncepcją masowej śmierci autorstwa Heideggera w wypadku masowych śmierci obozowych dochodzi do „wyrzucania ofiar masowej śmierci poza nawias tego, co jest ludzką śmiercią,43. „Śmierć nieumarła oznacza zatem, że sama śmierć została zniszczona jako śmierć, tak że nie można jej już rozpoznać, ani odnieść się do niej jako do śmierci’44. Przykładowo, w jednym z fragmentów u M. Riffera: „Lanci me peku na nogama, ne zato, što su se urezali u meso - fizičkih boli skoro i ne osjećam - nego zato, što nas od 400 »lančara« šeće po logoru još samo pet" ${ }^{\text {" }}$, w tym w eufemistycznym opisie dotyczącym wszechobecnego zjawiska masowej śmierci, nie jest istotny fakt, że spośród czterystu więźniów skutych łańcuchami zmarło w krótkim czasie trzysta dziewięćdziesiąt pięć osób, ale że pozostało przy życiu zaledwie pięciu. W drastycznych deskrypcjach nie pojawiają się pojęcia zwłok, nieboszczyka, trupa, zmarłego człowieka. Ich miejsce zajmują określenia typu: krwawa, postrzępiona masa mięsa.

Piccili je tukao, tukao beskrajno dugo, a Hirschberger je gazio teškim čizmama glavu žrtve. Lice žrtve bilo je već posve izobličeno, na njemu se više nisu razlikovali oči, usta, nos. Sve se pretvorilo u krvavu, razderanu masu mesa. Odijelo se na nesretniku raspalo,

${ }^{39}$ M. Riffer, Grad Mrtvih..., s. 47.

40 Ibidem, s. 64.

${ }^{41}$ Por. A. M. di Nola, Triumf śmierci. Antropologia żałoby, przeł. M. Surma-Gawłowska, Kraków 2006.

42 G. Agamben, Co zostaje..., s. 72, 77.

43 S. Ruszkowska, Każdemu własna śmierć. O przywracaniu podmiotowości ofiarom Zagła$d y$, Warszawa 2014, s. 87.

${ }^{44}$ Ibidem, s. 91.

${ }^{45}$ M. Riffer, Grad Mrtvih..., s. 66. 
a iz rasječenog tijela, već posve crna od teških udaraca, tekla je zgusnuta, ljepljiva krv. [...] $\mathrm{Na}$ podu ležala je masa krvavog mesa i razderanih krpa. Desna je noga bila ispod koljena slomljena. Iz crne krpe, koja je nekad bila sastavni dio hlača, virila je slomljena, krvava cjevanica $^{46}$.

W opisach Jakovljevicia i Riffera do najbardziej wstrząsających należą fragmenty dotyczące zjawiska kanibalizmu, a także pożarcia człowieka przez świnie.

U tome je logoru zabilježeno nekoliko slučajeva ljudožderstva. Među Židovima koji, ne mogavši podnositi glad, posegnuše za „državnim dobrom”, a sada, sasvim poludjevši, za čovječjim tijelom. U Staroj Gradiški to se nije događalo. Nitko nije toliko poludio da se baci na lešinu svojega druga. Požderan je, koliko znadem, samo jedan čovjek, ali ni njega ne požderaše ljudi [...] tamo mu staviše glavu u kotac. Naslađivali su se gledajući kako svinje trgaju sa živa čovjeka obraze, kako se odvratna njuška dotiče usana i nosa, kako pohlepni zubi glođu tu jadnu, nesretnu glavu, koja je sa svim mislima, sa svim snovima predana za hranu nečistoj životinji ${ }^{47}$.

W makabrycznej scenie kanibalizmu u Riffera „uczestnikami” zdarzenia stają się trzej agambenowscy muzułmanie ${ }^{48}$ oraz zdehumanizowane zwłoki:

Logoraši logora III C nisu dobivali hrane; [...] Morao sam se uhvatiti rukom za smradni, amonijakom izgriženi oluk pisoara, da se ne srušim. Pozlilo mi je od prizora, koji mi se ukazao nedaleko od žice logora III C. na snijegu sjedila su tri ljudska kostura i noževima kidali meso s gole lešine svoga mrtvog druga. Komade mesa trpali su neobično lakomo u usta i žvakali takvom brzinom, te sam čuo, kako im škljocaju zubi. Jedan je podigao nogu lešine i s nje strugao nožićem mršavo mišičje. [...] S druge strane žice nije bilo više nikoga; ležale su u hrpi samo oglodane kosti i odrezana bradata, siva glava pokojnika. Nju nisu pojeli ${ }^{49}$.

Ponownie pojawia się określenie lešina: ścierwo, padlina, odczłowieczające samo zjawisko śmierci (ludzkiej) oraz osobę zmarłego. Co ciekawe, trzej więźniowie-kanibale, zostali przedstawieni w opisie jako „tri kostura” (trzy szkielety), monstrualne, zdehumanizowane istoty. Makabryczność i tragizm zaistniałego zdarzenia potęguje fakt, że cała sytuacja miała miejsce w czasie Bożego Narodzenia, przez co skojarzenie świątecznej wieczerzy — rytualnego i obfitego posiłku w gronie bliskich — zostaje tu skonfrontowane z rzeczywistością obozową, „gdzie wszystko jest możliwe” (Arendt, Agamben), ponieważ trzej skrajnie wygłodzeni więźniowie spożywają łapczywie ciało towarzysza.

${ }^{46}$ Ibidem, s. 65.

${ }^{47}$ I. Jakovljević, Konclogor..., s. 166.

48 Według G. Agambena, podążającego za myślą M. Foucault (biopolityka gatunku ludzkiego), w warunkach obozowych dokonywała się często przemiana człowieka w zredukowaną do biologicznego życia substancję biopolityczną, pozbawioną tożsamości. Zdaniem E. Domańskiej: „Muzułman jako widziana z perspektywy historycznych realiów, znajdująca się na samym dnie hierarchii kategoria więźnia obozu zagłady lub obozu koncentracyjnego oraz wyłaniająca się z tekstów literackich i filozoficznych liminalna figura wyznaczająca nie-ludzki obszar człowieczeństwa stanowi ważny aspekt rozważań na temat ludzkiej kondycji w kontekście technologii władzy”, E. Domańska, Muzułman: świadectwo i figura, [w:] Zagłada. Współczesne problemy rozumienia i przedstawiania, red. P. Czapliński, E. Domańska, Poznań 2009, s. 67.

${ }^{49}$ M. Riffer, Grad Mrtvih..., s. 116-117. 
Ležao sam ukočen od užasa u hladnoj baraci, u mraku, uz panični hropac umirućih, opkoljen stravom jasenovačke noći, kroz koju su odjekivali hici iz ustaških pušaka u slavu rođenja otkupitelja naših, dakle i njihovih grijeha. U demonskom kolopletu tih suprotnih božičnih slika stajale su u pozadini lakome oči trojice logoraša, što su danas popodne, pomahnitali od gladi, jeli svoga mrtvog druga $[\ldots]^{50}$.

„Śmierć nieumarła” jest ponadto konsekwencją anonimowości, z której wyodrębnia się śmierć anonimowa. Przytaczając myśl H. Arendt:

obozy koncentracyjne uczyniły samą śmierć anonimową, [...] pozbawiły ją jej właściwego znaczenia końca spełnionego życia. [...] odebrały jednostce jej śmierć, dowodząc, że odtąd nic do niej nie należy, a ona nie należy do nikogo. Jej śmierć pieczętuje tylko fakt, że nigdy nie istniała naprawdę [...] jest śmiercią niczyją [...] traci swoje znaczenie, bo nikt jej nie opłakuje ${ }^{51}$.

W refleksji A. Baraca na temat rzeczywistości obozowej wystawiona na próbę jednostka zostaje pozbawiona tożsamości indywidualnej, którą zastępuje tożsamość kolektywna i anonimowość:

identitet je odmah po ulasku u logor stavljen na kušnju, vremenom se rastapa dok ne postane tek dio masovnoga određenja, a posebno zabrinjava neizvjesnost njegove budućnosti pri povratku u poslijeratnu svakondevicu. U kontekstu jedne zatvoreničke sobe sve ono što je definiralo pojedinog čovjeka prije dolaska u logor postaje nevažno; ministri, suci, profesori, znanstvenici i književnici tek našavši se obespravljeni u zatočeništvu, prljavi, pothlađeni, bolesni, gladni i žedni pokazuju svoje pravo lice; na mjesto njihovih dotadašnjih društvenih uloga dolaze neke druge, primjerice čistača ili ložača. [...] za ustaše zatočenici su tek brojevi unutar grupe čime dolazi do potpunoga gubitka osobnih karakteristika dok u jačanju otpora prema situaciji identitet prelazi u zajednički ${ }^{52}$.

W warunkach obozowych zmarły, wcześniej więzień/numer, zostaje pozbawiony najpierw tożsamości indywidualnej, następnie jednostkowej śmierci, by zostać zdegradowanym do rangi trupa, „masy mięsa”, ludzkiego ścierwa, padliny (lešina). Pragnieniem więźnia-Baraca staje się już nie wolność czy ocalenie życia, lecz odzyskanie własnej tożsamości, osobowości, jestestwa: „U noći, na svome krevetu, u svojoj sobi, htio bih opet da se snađem u osjećanju, da sam to opet ja, ličnost, slobodan i nevezan"53.

Tuż po drugiej wojnie światowej, mimo naturalnych oczekiwań, nie dokonały się w pożądanym stopniu próby rozliczenia polityki i zbrodniczej działalności ruchu ustaszowskiego i państwa A. Pavelicia. Jednakże w akcie rozrachunku z narodową przeszłością tematyka obozów koncentracyjnych, prześladowania Żydów, a także Serbów czy Romów stawiała Chorwatów w negatywnym świetle, czyniąc ich „depozytariuszami” i zwolennikami ideologii faszystowskiej. W czasie trwania Jugosławii Tity przemilczanie prawdy o ustaszowskich obozach i polityce czystek etnicznych miało na celu podtrzymywanie idei brater-

\footnotetext{
50 Ibidem, s. 118.

51 S. Ruszkowska, Każdemu własna..., s. 107.

52 J. Dragičević, Barčev Bijeg..., s. 290-291.

53 A. Barac, Bijeg od knjige, Zagreb 1965, s. 205.
} 
stwa i jedności. Autobiograficzne teksty o miejscach takich jak Jasenovac i Stara Gradiška wyszły spod pióra świadków powodowanych obowiązkiem pamiętania, zdeterminowanych, za Bożeną Karwowską: „imperatywem moralnym, jako rodzaj symbolicznej zemsty na oprawcach, czasem jako myśl dająca siły do przetrwania"54. Zdaniem Przemysława Czaplińskiego: „Teksty o Holokauście są przekazami pełniącymi inne funkcje niż estetyczne" ${ }^{55}$. W literaturze o Zagładzie, będącej przede wszystkim zasobem narracji tanatologicznych i doświadczeń granicznych, jakim jest śmierć (masowa), pojawia się problem języka opisu (wyrażanie niewyrażalnego/opisywanie nieopisywalnego), o czym wspomina choćby D. LaCapra ${ }^{56}$. Język wypowiedzi często staje się bezradny wobec prób opisu realiów obozowych, jednakże ocalały: „Więzień musi napisać, czytelnik MUSI przeczytać" ${ }^{7}$. Jak zauważa Stanisław Rosiek: „Nastąpiła dewaluacja słów o śmierci. [...] Należy mówić mało i jak najprościej. Brzydko. Słowa o śmierci powinny wydzielać trupi odór"58. We współczesnej optyce przywołane (auto) tanatografie obszaru postjugosłowiańskiego są przedmiotem refleksji na temat stosunku do śmierci ukształtowanego pamięcią o Holokauście. Zdaniem M. Riffera historia tych obozów nie była w owym czasie należycie nagłośniona. Autor i były więzień ubolewał, że milczy się na temat Jasenovaca, który jako miejsce ludzkiego okrucieństwa, stworzone przez faszystowski reżim na terenie Chorwacji, swoją „rangą” w niczym nie ustępował miejscom takim jak Auschwitz, Mauthausen czy Ravensbrück.

\section{Bibliografia}

Agamben G., Co zostaje z Auschwitz, przeł. S. Królak, Warszawa 2008.

Arendt H., Korzenie totalitaryzmu, przeł. D. Grinberg, M. Szawiel, Warszawa 2014.

Barac A., Bijeg od knjige, Zagreb 1965.

Buryła S., Prawdy niechciane i potrzeba ich społecznej artykulacji, [w:] Pamięć Shoah. Kulturowe reprezentacje i praktyki upamiętniania, red. A. Ziedler-Modlewska, T. Majewski, Łódź 2011.

Ciliga A., Jasenovac: ljudi pred licem smrti. Uspomene iz logora, Zagreb 2011.

Czapliński P., Zagłada jako wyzwanie dla refleksji o literaturze, „Teksty Drugie” 2004, nr 5.

Danek D., Śmierć wewnętrzna. Literatura w świetle doświadczenia psychoanalitycznego, Gdańsk 2012.

Domańska E., Muzułman: świadectwo i figura, [w:] Zagłada. Wspótczesne problemy rozumienia i przedstawiania, red. P. Czapliński, E. Domańska, Poznań 2009.

Dragičević J., Barčev Bijeg od knjige, [w:] Zbornik o Antunu Barcu, red. T. Maštrović, Zagreb 2014. Nola A. M. di, Triumf śmierci. Antropologia żałoby, przeł. M. Surma-Gawłowska, Kraków 2006.

${ }^{54}$ B. Karwowska, Wspomnienia z obozu zagłady jako tekst autobiograficzny, [w:] Autobiografie (po)graniczne, red. I. Iwasiów, T. Czerska, Kraków 2016, s. 126.

55 P. Czapliński, Zagłada jako wyzwanie dla refleksji o literaturze, „Teksty Drugie” 2004, nr 5, s. 19.

${ }^{56}$ D. La Capra, Historia w okresie przejściowym. Doświadczenie, tożsamość, teoria krytyczna, przeł. K. Bojarska, Kraków 2009, s. 12.

57 Z. Kossak-Szczucka, Z otchtani, Rzym 1946, s. 3.

${ }^{58}$ S. Rosiek, Wstęp, [w:] Wymiary śmierci..., s. 5. 
Jakovljević I., Konclogor na Savi, Zagreb 1999.

Karwowska B., Wspomnienia z obozu zagłady jako tekst autobiograficzny, [w:] Autobiografie (po) graniczne, red. I. Iwasiów, T. Czerska, Kraków 2016.

Kossak-Szczucka Z., Z otchłani, Rzym 1946.

La Capra D., Historia w okresie przejściowym. Doświadczenie, tożsamość, teoria krytyczna, przeł. K. Bojarska, Kraków 2009.

Mataušić N., Jasenovac 1941.-1945. Logor smrti o radni logor, Jasenovac-Zagreb 2003.

Miliša Đ., U mučilištu-paklu Jasenovac, Zagreb 2011.

Riffer M., Grad Mrtvih Jasenovac 1943, Zagreb 2011.

Rosiek S., Wstęp, [w:] Wymiary śmierci, red. D. Dmochowska, T. Swoboda, Gdańsk 2010.

Ruszkowska S., Każdemu własna śmierć. O przywracaniu podmiotowości ofiarom Zagłady, Warszawa 2014.

Thomas L. V., Tworzenie tanatologii, przeł. M. L. Kalinowski, [w:] Wymiary śmierci, red. D. Dmochowska, T. Swoboda, Gdańsk 2010.

Trifunčić R. Jasenovac, Daruvar 1974.

Ubertowska A., Holokaust. Auto(tanato)grafie, Warszawa 2014.

Vovelle M., Historia ludzi w zwierciadle śmierci, przeł. M. Ochab, [w:] Wymiary śmierci, red. D. Dmochowska, T. Swoboda, Gdańsk 2010.

\section{Notes from "the city of the dead": Jasenovac and Stara Gradiška concentration camps in thanatological narratives and in the memory discourse of the post-Yugoslav area}

\section{Summary}

This paper discusses selected Holocaust narratives of the post-Yugoslav area, which were set in the history of (Hitler's) Europe due to the establishment of the pro-Nazi Pavelić regime (The Independent State of Croatia). They were also set in the context of the concealment policy, when both places and events related to concentration camps, Jasenovac and Stara Gradiška, were ousted from collective memory by the authorities of communist Yugoslavia. Concentration camp memoirs and records - auto(thanato)graphies (J. Derrida, A. Ubertowska) - reflecting on the post-Yugoslav area of Tito's epoch had been a tabooed realm of unsolicited truths (S. Buryła) for a few decades due to political reasons and have recently been reintroduced into official discourse of memory. They also address the questions of the end of Western civilisation, the topos of the concentration camp as the territory of the reign of death and struggle for survival. The five selected thanatological testimonies present the Holocaust and the nightmare of World War II as an essential part of reflection on the human condition (H. Arendt) and they also show the phenomenon of collective trauma (D. LaCapra).

Keywords: thanatology narratives, Holocaust testimonies, death, collective memory, konclogor: Jasenovac/Stara Gradiška 


\section{Bilješke iz „Grada Mrtvih”. Konclogor Jasenovac i Stara Gradiška u književnim tanatološkim naracijama i u diskursu kolektivnog pamćenja na području bivše Jugoslavije}

\section{Rezime}

Predmet razmatranja u ovom tekstu su odabrani autobiografski zapisi o Holokaustu sa područja bivše Jugoslavije, stavljene u vizuru povijesti (hitlerove) Europe povodom osnivanja režima Ante Pavelića kakva je bila NDH. Istodobno vrlo je važan u ovoj analizi kontekst politike prešućivanja te brisanja iz kolektivnog pamćenja mjesta i događaja vezanih uz logore smrti: Jasenovac i Stara Gradiška koje su vlasti komunističke Jugoslavije nakon II svjestkog rata uspješno poricale. Vraćene u zadnje vrijeme javnom pamćenju sjećanja i uspomene na logor - ,auto(tanato) grafije (J. Derrida, A. Ubertowska) - bile su nekoliko decenija prešućivane ili od javnosti skrivane u Titovoj državi te zbog političkih razloga spadale su u zonu nepoželjnih istina (S. Buryła). Zabilježena vlastita sjećanja na konclogora - kasnije proskribiranih autora/svjedoka - bave se univerzalnom temom smrti, rušenja civilizacije zapadnog kruga, konclogora kao područja svevladajuće smrti, istrebljivanja i životnjske borbe za preživljavanje zatočenika. Pet odabranih logorskih testimonija prikazuje traumu II svjestkog rata (D. LaCapra) te govori o stanju čovječanstva u postratnom razdoblju (H. Arendt).

Ključne riječi: tanatološke naracije, svjedočenja o Holokaustu, smrt, kolektivno pamćenje, konclogor: Jasenovac/Stara Gradiška 